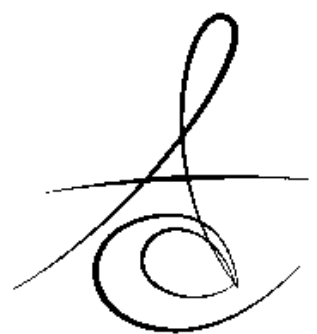

Makale Kodu/Article code: 1512

Makale Gönderilme tarihi: 12.02 .2014

Kabul Tarihi: 28.04.2014

\section{DENTAL PROTETİK MATERYALLERE MİKROORGANİZMA TUTUNUMU}

\author{
MICROORGANISM ADHESION ON DENTURE MATERIALS
}

Dt. İrem TÜRKCAN*

Prof. Dr. A. Dilek NALBANT*

\section{ÖZET}

Dental protetik restorasyonlar, ağız içindeki kaybolmuş fonksiyon ve estetiğin yerine konması için yapılan uygulamalardır. Doğal dişler ve ağız içi dokularda olduğu gibi protezler de, mikroorganizmaların tutunması için uygun bir ortam sağlamaktadır. Sabit ve hareketli protez materyalleri üzerinde oluşan biyofilm, konumu nedeniyle zararsız gibi görünse de sonuçları şiddetli olabilmektedir. Bu derlemenin amacl, farklı protetik materyallerde mikroorganizma tutunumu ve biyofilm oluşumunun, konuyla ilgili yapılan araştırmalar ışı̆̆ında incelenmesidir.

Anahtar kelimeler: diş protezi, biyofilm, bakteriyel yapışma

\section{DENTAL PROTETİK MATERYALLERE MİKROORGANİZMA TUTUNUMU}

Biyofilm, tabana veya birbirine geri dönüşümsüz olarak yapışan ve mikroorganizmalar tarafından üretilen ekstraselüler polimerik maddeden oluşan bir matriks içerisine gömülü hücreler ile karakterize, çeşitli mikrobiyal türlerden oluşan bir topluluktur. Biyofilmler; su boruları, doğal su sistemleri, canlı dokular, diş yüzeyleri, kalıcı tıbbi cihazlar ve implantlar gibi çok çeşitli yüzeylerde oluşabilmektedir. ${ }^{1}$

Biyofilmler, doğal ortama açık tüm yüzeylerde oluşabilir. Oral kavitedeki biyofilm oluşumu buna iyi bir örnektir. ${ }^{2}$ Ekolojik açıdan bakııdığında oral kavite ve orofaringeal bölge, bir "açık büyüme sistemi"dir. Bu sistem, hem mikroorganizmaların hem de besinlerin kesintisiz giriş ve çıkışlarına maruz kalır. Orofaringeal bölgede hayatta kalabilmek için bakteriler, makaslama kuvvetlerine karşı koyabilmek amacıyla yumuşak veya sert dokulara tutunma intiyacı duyarlar. Oral epitelin hızlı döngüsü etkili bir savunma mekanizması sağlar ve

\section{ABSTRACT}

Dental prosthetic restorations are applications used for the replacement of missing function and aesthetics in the oral cavity. Dentures, as well as natural teeth and oral tissues, provide a convenient environment for the adhesion of microorganisms. Although the biofilm on fixed and removable denture materials may seem to be harmless due to its location, the consequences might be severe. The aim of this paper is to review the microorganism adhesion and biofilm formation on different denture materials in the light of previous studies.

Key words: dental prosthesis, biofilm, bacterial adhesion böylece büyük miktarlarda bakteri birikimi önlenmiş olur. Ancak, dökülmeyen yüzeylere sahip olan dişler, protezler veya endoosseöz implantlar, kalın biyofilmlerin oluşmasına olanak sağlarlar. Genellikle, oluşan biyofilm konak ile bir denge içerisinde varlığını sürdürür. Ancak, bakterinin sert dokulardaki kontrolsüz akümülasyonu ve/veya metabolizması, çürük, gingivitis, periodontitis, peri-implantitis ve stomatitlerin temel sebebidir. ${ }^{3}$

Sadece dental sert ve yumuşak dokularda değil, oral kavitedeki fonksiyonun restorasyonunda kullanılan biyomateryallerin yüzeylerinde de biyofilm oluşmaktadır. Biyomateryaller üzerinde oluşan biyofilm, konumu nedeniyle zararsız görünse de sonuçları şiddetli olabilmektedir. ${ }^{2}$ Dental restoratif materyallerin yüzeylerinde biyofilm oluşması sonucunda, oral patojenik bakteriler çürüklere, periodontitise ve periimplant enflamasyonlara neden olabilirler. ${ }^{4}$ Dolayısıyla, biyofilm oluşumunun kontrol altında tutulması hastalar ve hekimler açısından önemini koruyan bir konudur.

*Gazi Üniversitesi Diş Hekimliği Fakültesi, Protetik Diş Tedavisi Anabilim Dalı 
$\mathrm{Bu}$ makalenin amacı, farklı protetik materyallerde mikroorganizma tutunumu ve biyofilm oluşumunun, konuyla ilgili yapılan araştırmalar ışığında incelenmesidir.

\section{Biyoadezyon Süreci ve Biyofilm Oluşumu}

Mikroorganizmalar ve taban yüzeyleri, organik materyalin de bulunduğu sıvı bir ortamda ise (örn. deniz suyu, süt, gözyaşı, idrar, kan veya tükürük), saniyeler içerisinde, yüzeye tutunmuş bir organik molekül tabakası ile kaplanırlar. ${ }^{3}$ Oral kavitede oluşan ve pellikıl denilen bu tabaka, oral yüzeylerdeki bakteri içermeyen başlangıç tabakası olarak tanımlanır. Pellikıl, glikoproteinler (müsinler), prolinden zengin proteinler, fosfoproteinler (örn. staterin), histidinden zengin proteinler, enzimler (örn. a-amilaz) ve bakteri için adezyon bölgesi görevi yapabilecek diğer molekülleri içeren çok sayıda bileşenden oluşmaktadır. Pellikıl öncül proteinleri olarak adlandırılan, hidroksiapatite yüksek afiniteye sahip fosfoproteinler, diş yüzeyine ilk tutunanlardır. Bu etkileşim, mine yüzeyindeki fosfat tabakası ve iyonik kalsiyum tarafından gerçekleştirilir. ${ }^{5}$ Böylece, bakteriyel adezyon pellikılla kaplanmış bakteri ile pellikılla kaplanmış yüzey arasında meydana gelir. ${ }^{3}$

Tükürükteki protein bileşimininden farklı protein içeriğine sahip olması (tükürükteki proteinlerin yalnızca bir kısmının pellikılda bulunması) pellikılın, çevresel makromoleküllerin seçici adsorpsiyonu sonucu oluştuğuna işaret etmektedir. ${ }^{5}$ Pellikılın fizikokimyasal yüzey özellikleri, alttaki sert yüzeyin fiziksel ve kimyasal doğasına büyük ölçüde bağlıdır. Bu nedenle, alttaki sert yüzeyin özellikleri pellikıl tabakaları boyunca iletilir ve böylece başlangıç bakteri adezyonunda etkisi olur. ${ }^{3}$ vardır: ${ }^{3}$

Bakteriyel adezyon için kabul edilen iki teori

1. Spesifik biyokimyasal mekanizma

2. Non-spesifik fizikokimyasal mekanizma

1. Spesifik Biyokimyasal Mekanizma:

Bakteri ve pellikıl arasındaki bağlantı çoğunlukla, organizmadaki spesifik ekstraselüler proteinimsi bileşenler (adhesinler) ve yüzeydeki tamamlayıcı reseptörler (örn. proteinler, glikoproteinler veya polisakkaritler) tarafından oluşturulur ve türlere özgüdür. Çoğu bakteri, tutunma için farklı spesifik mekanizmalara sahiptir. Yüzeyde tek bir katman oluştuktan sonra, tutunan türlerin çoğalması ve/veya yeni türlerin tutunmasıyla biyofilm oluşumu başlayabilir. Bu aşamadan sonra ortama yeni mekanizmalar da eklenir.3,6,7

\section{Non-Spesifik Fizikokimyasal Mekanizma:}

Oral kavitede olduğu gibi, sıvı ortamda bulunan dökülmeyen yüzeyde biyofilm oluşumu dört aşama olarak tanımlanmıştır. ${ }^{3}$

Faz 1 (yüzeye taşınma): Bakterinin yüzeye ilk yaklaşması, Brownian hareketi (ortalama yer değiştirme $40 \mu \mathrm{m} / \mathrm{sa}$ ), bakterinin çözeltideki sedimentasyonu, sıvı akışı veya aktif bakteri hareketi (kemotaktik aktivite) aracılığıyla meydana gelmektedir. ${ }^{3}$

Faz 2 (başlangıç adezyonu): Bu aşamada, bakterilerin yüzey ile belirli bir uzaklıktaki (50nm) uzun ve kısa mesafeli etkileşimleri aracılığıyla, zayıf ve geriye dönebilir bir bağlantı oluşur. Farklı non-spesifik etkileşim kuvvetlerinin bileşkesine bağlı olarak, bu organizmalar yüzey tarafından çekilir veya itilir. ${ }^{3}$

Faz 3 (bağlantı): Bakteri ve yüzey arasında temas sağlandıktan sonra, doğrudan ya da boşluğun köprülenmesiyle (fimbria), özel etkileşimler (kovalent, iyonik veya hidrojen bağlantısı) tarafından bakteri ve yüzey arasında sıkı bir ankraj kurulabilir. ${ }^{3}$

Faz 4 (kolonizasyon/plak maturasyonu): Sıkı bağlanmış mikroorganizmalar büyümeye başladığında ve yeni oluşan hücreler de bağlandığında biyofilmler gelişebilir. Pürüzlü yüzeyde bakteriler makaslama kuvvetlerinden daha iyi korunduğu için, geri dönebilir bağlantıdan geri dönemez bağlantıya geçiş daha kolay ve sık meydana gelir. ${ }^{3}$

Teughels ve arkadaşları ${ }^{3}$, materyalin yüzey özelliklerinin (serbest enerji, pürüzlülük, kimyasal yapı) özellikle supragingival ve bir dereceye kadar da subgingival biyofilm oluşumundaki etkisini inceleyen çalışmaları derlemişlerdir. Yüzey pürüzlülüğünün 0.2 $\mu m^{\prime} l i k$ eşik değerin üzerine çıkmasının veya yüzey serbest enerjisinin artmasının, restoratif materyaller üzerinde biyofilm oluşumunu kolaylaştırdığı ve yüzey pürüzlülüğünün daha baskın bir etkisi olduğunu ve biyofilm oluşumunun aynı zamanda biyomateryal tipi (kimyasal bileşim) ve kaplama tipi tarafından da etkilendiğini belirtmişlerdir.

\section{Protetik Materyallerdeki Biyofilmler}

Protez yüzeyinde oluşan pellikılın içeriği dişler üzerinde oluşan pellikıldan farklılık gösterir. Protez yüzeyindeki pellikıl a-amilaz, yüksek molekül ağırlıklı müsin, lizozom ve sIgA içerirken, düşük molekül ağırlıklı müsin, sistatin ve prolinden zengin protein içermez. ${ }^{8}$

Protez plağı mikroorganizmaları ve metabolitlerinden oluşan, yoğun, karmaşık heterojen 
bir tabakadır. ${ }^{9}$ Protez plağı, tükürük, oral mukoza ve uygun protez hijyeni yokluğunda muhtemelen parmaklardan mikroorganizmaların tutunma, toplanma ve büyümesi ile gelişir; tükürük, oral mukoza ve yiyeceklerden besin elde eder. Plak daha çok, ağızdaki mekanik kuvvetlerden ve akımdan koruma sağlayan durgun alanlarda birikir ve protez bu alanlara fazlasiyla sahiptir. ${ }^{10,11}$ Protezlerin doku yüzeyindeki durgun alanlarda plak daha asidojenik olmaya eğilimlidir. Bu durum Streptokok ve Candida türlerinin lehine olduğu için, bu mikroorganizmalar protezlerin doku yüzeylerinde daha sık bulunur. Ek olarak, daha fazla besin birikimi, düşük tükürük akış oranı ve pürüzlü topografi de plağı destekler ve korur. ${ }^{11,12}$

Protez plağı, mikrobiyal suşların birikimi için bir film tabakası görevi görür ve belli bir bölgede bırakılırsa kalsifiye olabilir ve tartar ya da diş taşı oluşabilir, uzaklaştırıması için diş taşlarının kazınmasını gerekir. ${ }^{11}$

Protez plağı mikrobiyolojisi ile ilgili az sayıda çalışma mevcuttur. Literatürdeki çalışmaların çoğu, protez kaynaklı stomatitin etyolojik ajanı, Candida albicans ve ilgili nedensel faktörler (zayıf protez hijyeni ve sonucunda oluşan plak birikimi) üzerine odaklanmaktadır. ${ }^{11,13,14}$ Protez plağının mikrobiyolojisi diş plağı ile karşılaştırıması da az ilgi görmüştür. Konum (en problemli protez plağı maksillaya temas eden yüzeyde görülür) ve bileşim (artmış mantar varlığı intimali) bakımından farklıık gösterir; ancak özellikle zorunlu anaeroblardan oluşan genel bileşim kötü tanımlanmışıı. Gram negatif çomakların nispeten az, Gram pozitif koklar ve kısa rodların baskın olduğu protez plağı bileşiminin diş plağı ile oldukça benzer olduğu genel kanısı mevcuttur. ${ }^{11}$

Plak mikroflorası bireyler arasında, ağzın farklı bölgelerinde ve protez üzerinde değişkenlik gösterse de protez plağı mikroflorasının üretilebilen baskın türleri; Streptococcus spp. (S. sanguinis, S. oralis, S. anginosus, S. salivarius), Staphylococcus spp. ( $S$. aureus, S. epidermidis), Gram pozitif çomaklar (Actinomyces spp., Lactobacilli, Propionibacterium spp., Veillonella spp.), Gram negatif çomaklar ve mantarlardır. Protez plağında baskın mikrobiyal türler arasında Streptococcus mutans'in bulunmaması önemlidir; çünkü $S$. mutans diş plağında baskındır ve etiyolojik olarak diş çürüğü ile ilişkilidir. ${ }^{11}$

Protez plağı, dental plak ile karşılaştırıldığında, büyük oranda zorunlu anaerobik Actinomyces spp. ( $A$. israelii), düşük oranda Gram negatif çomak ve deri bakterisi olan Staphylococcus aureus'un olağan varlığı bildirilmiştir. ${ }^{11,15,16}$ Protez plağı ile ilgili bir çalışmada, örneklerin \%27'si $S$. aureus ile kolonize olmuştur. Kolonize olan örneklerin ise $\% 1^{\prime} \mathrm{i}$ metisiline dirençli $S$. aureus (MRSA)tur. ${ }^{17}$

Biyofilm oluşumu ile ilgili çeşitli materyaller üzerinde yıllardır çalışmalar yapılmaktadır. Klinikte en sık kullanılan protetik materyallerde biyofilm oluşumu aşağıdaki başıklar altında toplanabilir:

a. Akrilik rezinde biyofilm

b. Yumuşak astar materyallerinde biyofilm

c. Seramikte biyofilm

d. Metal alaşımlarında biyofilm

e. Yapıştıııcı simanda biyofilm

f. Titanyum ve zirkonyada biyofilm

\section{Akrilik Rezinde Biyofilm}

Teles ve arkadaşlarının ${ }^{18}$ yaptıkları bir çalışmada, dişli ve dişsiz hastalarda profesyonel temizlikten önce ve sonra örnekler alınarak erken biyofilmdeki mikrobiyal farklııklar karşılaştırımıştır. Temizlik öncesi biyofilm miktarı benzerken, temizlik sonrası erken biyofilm miktarının dişli hastalarda daha çok ve daha karmaşık olduğu belirtilmiştir. Temizlik öncesi dişsiz hastalardaki biyofilmde $S$. mitis, $S$. oralis ve $S$. mutans miktarının, dişli hastalarda ise temizlik öncesinde Tannerella forsythia, Selenomonas noxia ve Neisseria mucosa miktarının fazla olduğu bildirilmiştir. Temizlik sonrası biyofilmin doğal dişlerde protezlerden daha hızlı geliştiği ve daha karmaşık olduğu tespit edilmiştir.

Akrilik yüzeylere bakteriler de tutunsa, akrilik protezlerin kullanımındaki en büyük sorun, stomatite yol açan Candida tutunumudur. ${ }^{19,20}$ Yüksek derecede enflamasyona sahip hastaların protezlerinden en çok izole edilen oral mantar Candida albicans'tır. C. albicans, sağlıklı bireylerde gastro-intestinal ve üreme sistemlerinde bulunan komensal dimorfik bir mantardır. ${ }^{21,22}$ C. albicans oral kavitede en çok, farklı bakteri suşlarının da bulunduğu karışı bir biyofilmde saptanır. ${ }^{23}$ Bakteriyel adezyonun, Candida adezyonunu arttırdığı öne sürülmüştür; akrilik yüzeyin ağız ortamına açımasından saatler sonra bakteriler görülürken, mantarların günler sonra görülmesi bu teorinin mümkün olabileceğini göstermektedir. ${ }^{2,24}$

Pereira ve arkadaşlarının ${ }^{25}$ yaptıkları çalışmada, yüzey pürüzlülüğü $(R a)$, yüzey serbest enerjisi (SFE), tükürük ve bakterinin protez materyallerinde Candida adezyonu üzerindeki etkisi araştırımışır. Candida 
kolonizasyonunun tükürük tarafından anlamlı derecede azaltıldığı ve bakteri tarafından arttırıldığı bildirilmiştir. Candida adezyonu Ra, tükürük ve bakteriden fazlasıyla etkilenirken, SFE'den etkilenmemiştir.

Fungal biyofilmlerin mekanik veya kimyasal olarak uzaklaştırılması önemli bir klinik problemdir. Muhtemelen protez yüzeyindeki mikropörözitenin bir sonucu olarak, mantarların protez kaide materyallerine oldukça kuvvetli bağlandığı bilinmektedir. Protez kaide materyallerinin pürüzlülüğü arttıkça $C$. albicans adezyonu da artmaktadır. ${ }^{2,26-28}$

Akrilik protez kaidesinde biyofilm oluşumunun inhibisyonu üzerine birçok çalışma yapılmıştır. Wady ve arkadaşları $^{29}$, gümüş nanopartikül solüsyonunun antifungal etkiye sahip olmasına rağmen akriliğin içerisine katıldığında $C$. albicans adezyonu ve biyofilm oluşumu üzerinde bir etkisinin olmadığını bildirmişlerdir. Başka bir çalışmada ise, içerisine gümüş nanopartikül katılan polimetil metakrilat kaide materyalinde $C$. albicans tutunmasının anlamlı derecede azaldığı belirtilmiştir. $^{30}$

Protez temizleme solüsyonları sadece oral streptokokları öldürmekle kalmaz, aynı zamanda akrilik yüzeyi de koşullandırır. Akrilik yüzeylerin temizleyici ile koşullandırıması, su ile muamele edilmiş akrilik yüzeyinde oluşan tek tabaka biyofilmin uzaklaştırılmasından daha kolay olan çok katlı $s$. oralis biyofilminin in vitro oluşumunu teşvik etmektedir. ${ }^{31}$ Bakteriyel adezyonun, fungal biyofilm oluşumu için gerekli bir basamak olma ihtimali göz önüne alındığında, streptokokal biyofilmin uzaklaştırılması maya da içeren daha patojenik bir biyofilmin oluşumunu önleyebilir. Son yıllarda, polietilen oksitle modifiye edilmiş protez kaide materyallerinde in vitro $C$. albicans oluşumunun azaldığı bildirilmiştir. ${ }^{2,27}$

Nalbant ve arkadaşlarının ${ }^{13}$, palatal mukozaya ve akrilik protez yüzeylerine Candida adezyonu üzerinde iki farklı temizleme ajanının (Klorhex ve Fittydent) etkilerini karşılaştırdıkları çalışmalarında, bu ajanların in vitro uygulanmasından sonra mantarların akrilik şeritlere adezyonu incelenmiştir. 15'er hastadan oluşan gruplar protezlerini Klorhex veya Fittydent ile temizlemiş, kontrol grubu ise protez temizliği için su kullanmıştır. Hastaların \%62.2'sinde palatal mukozada Candida kolonileri saptanmıştır ve temizleme ajanlarının kullanılmasından sonra bu oran \%51.1'e düşmüştür. Protezlerdeki Candida kolonizasyonu ise temizleme ajanlarının kullanılmasından sonra \%82.2'den \%68.8'e düşmüştür. Akrilik şeritlerden izole edilen Candida türlerinin ortalama adezyon değerleri 75 hücre/şerit iken, Klorhex ve Fittydent uygulandıktan sonra sırasıyla 37.5 hücre/şerit ve 15 hücre/şerit değerlerine düşmüştür. Sonuç olarak; palatal mukozada, protezlerde ve akrilik şeritlerde in vitro Candida birikiminde temizleyici ajanların önleyici etkisinin olduğu gösterilmiştir.

\section{Yumuşak Astar Materyallerinde Biyofilm}

Sert akriliklere göre yumuşak astar maddelerinin pürüzlü yüzeyleri, plak ve diştaşı birikimine yol açmakta, mantar ve benzeri organizmaların üremesine uygun bir ortam hazırlamaktadır. Bu materyallerin temizleme güçlüğü, ortamdaki birikimi daha da arttırmaktadır. ${ }^{32}$

Boscato ve arkadaşlarının ${ }^{33}$ yaptıkları bir çalışmada, oral hijyen yöntemlerinin yumuşak astar materyalinde biyofilm oluşumu üzerindeki etkisi 6 hafta süresince incelenmiştir. Günlük temizlik için diş fırçası ve diş macunu kullanmış hastalarda en düşük biyofilm oluşumu gözlemlenmiştir. Macun ve fırçaya ilaveten haftada bir kez sodyum hipoklorit kullanan hastalarda, yumuşak astar materyalinde düzensizlerin oluştuğu ve dolayısıyla biyofilm miktarının arttığı bildirilmiştir.

Tarı ve arkadaşlarının ${ }^{28}$ yaptıkları çalışmada, tükürük ile kaplanmış ve kaplanmamış, hızlandırılmış yaşlandırma testi uygulanan 3 farklı yumuşak astar materyalinde (Visco Gel, Ufi Gel P ve Molloplast B) yüzey pürüzlülüğü ve $C$. albicans tutunumu araştırılmıştır. Yaşlandırma işleminin yumuşak astar materyallerinin yüzey pürüzlülüğünü arttırdığı bildirilmiştir. Yaşlandırma işlemi uygulanan Visco Gel'in yüzey pürüzlülüğü, Ufi Gel $P$ ve Molloplast B'den anlamlı derecede yüksek bulunmuştur. Yaşlandırılmamış ve tükürük ile kaplanmamış materyaller arasında anlamlı fark görülmezken; yaşlandırılmış ve tükürük ile kaplanmamış yumuşak astar materyallerinde $C$. albicans'ın daha fazla tutunumu görülmüştür. Yaşlandırılmamış ve tükürük ile kaplanmış materyallerde anlamlı fark görülmezken, yaşlandırılmış ve tükürük ile kaplanmış yumuşak astar materyallerinde C. albicans'ın daha fazla tutunumu görülmüştür.

Bal ve arkadaşlarının ${ }^{14}$ farklı yumuşak astar ve akrilik rezin yüzeylerinde oral mikroorganizmaların adezyonunu karşılaştırdıkları çalışmalarında, 17 hastanın protezlerinin doku yüzeylerinde oluşturulan boşluklara 3 farklı yumuşak astar materyali (Ufi Gel P, 
Softliner, Coe Soft) uygulanmıştır. Test edilen 4 materyal arasında en fazla oral mikroorganizma tutunan materyal Softliner olmuştur. Yumuşak astar materyallerinde akrilik rezinden daha fazla miktarda oral bakteri ve Candida görüldüğü bildirilmiştir. Mikrobiyal tutunum zaman içinde artmış ve 1 ile 14 . günler arasında istatistiksel olarak anlamlı fark bulunmuştur. Çalışmanın sonucunda, geçici yumuşak astar materyallerinin adezyona ve oral bakteriler tarafından oluşturulması muhtemel yüzey hasarına dirençli olmadığı; bu nedenle kullanımlarının kısa süre ile kısıtlanması gerektiği belirtilmiştir.

\section{Seramikte Biyofilm}

Seramik yüzeylerdeki biyofilm hakkında az bilgi vardır. Yapılan çalışmalarda, seramik yüzeyinde doğal dişlere göre daha az ve canlılı̆ı azalmış plak tespit edilmiştir. Altın ve amalgam (11-17 $\mu \mathrm{m})$ ile karşılaştırıldığında, seramik biyomateryallerde 5 gün boyunca in vivo oluşan biyofilm daha ince (1-6 $\mu \mathrm{m})$, ancak daha canlıdır (\%34-\%86). Besin kaynağının engellenmesine bağlı olarak, kalın biyofilmler incelerden daha az canlıdır. ${ }^{2}$

Bremer ve arkadaşlarının ${ }^{4}$ yaptığı in vivo bir çalışmada 5 farklı seramik materyali (veneer cam seramik, lityum disilikat cam seramik, itriyum stabilize zirkonya (Y-TZP), sıcak izostatik preslenmiş (HIP) YTZP seramik ve \%25 alümina içeren HIP Y-TZP seramik) üzerinde biyofilm oluşumu incelenmiştir. En düşük yüzey kaplanması (\%19.0) ve biyofilm kalınlığı (1.9 $\mu \mathrm{m})$ HIP Y-TZP seramiklerde tespit edilirken; en yüksek ortalama değerler lityum disilikat cam seramikte görülmüştür (\%46.8, $12.6 \mu \mathrm{m})$.

Hahnel ve arkadaşları ${ }^{34}$, farklı dental seramik materyallerinin (cam, lityum disilikat cam, cam-infiltre zirkonya, yarı sinterize zirkonya, sıcak izostatik presleme zirkonya seramik) yüzey özelliklerinin in vitro başlangıç streptokokal adezyonu üzerindeki etkisini araştırmışlardır. Lityum disilikat cam seramik en yüksek yüzey pürüzlülüğünü gösterirken, en düşük değerler cam seramik, yarı sinterize zirkonya ve sıcak izostatik presleme zirkonya seramikte görülmüştür. Sonuç olarak, dental seramik materyallerin yüzey pürüzlülüğü, yüzey serbest enerjisi ve başlangıç streptokokal adezyon açısından farklılıklar gösterdiği; ancak yüzey özellikleri ve streptokokal adezyon arasındaki korelasyonun zayıf olduğu bildirilmiştir.

Aykent ve arkadaşlar ${ }^{35}$, seramik ve 3 farklı kompozit (2 indirekt ve 1 direkt kompozit rezin) materyallerinde yüzey pürüzlülüğü ve bakteriyel adezyon arasındaki ilişkiyi incelemiştir. Yüzey pürüzlülüğü restoratif materyal tipine ve yüzey işlemlerine göre anlamlı farklılık göstermiş, restoratif materyal ve yüzey işlemi arasında anlamlı ilişki bulunamamıştır. Seramik, bu materyaller içinde en az yüzey pürüzlülüğüne sahip (direkt kompozit rezin materyalinden sonra) ikinci materyal olmuştur. Bakteriyel adezyon açısından materyaller arasında anlamlı farklılık bulunurken, yüzey işlemleri arasında anlamlı fark bulunmamıştır. En düşük bakteriyel adezyon seramik yüzeyinde gözlemlenmiştir. Yüzey işlemlerinden bağımsız olarak, bakteri adezyonu açısından materyaller arasındaki anlamlı fark, materyal yüzeyinin kimyasal kompozisyonunun bakteri adezyonu için önemli olduğu gösteriImiştir.

Kawai ve arkadaşlar ${ }^{36}$, bakteri adezyonu ve glukan sentezi üzerinde porselenin yüzey pürüzlülüğünün etkisini araştırdıkları çalışmalarında, elmas patla polisajlanan yüzey en pürüzsüz yüzey olmuştur; bunu sırasıyla glazelenmiş yüzey ve 600 grenli zımpara kâğıdı ile polisajlanmış yüzey takip etmiştir. En pürüzlü yüzey ise 120 grenli zımpara kâğıdı ile polisajlanmış yüzey olmuştur. En düşük bakteri ve protein tutunumunu elmas patla polisajlanmış yüzey göstermiştir. En fazla miktarda plak, en pürüzlü yüzey olmamasına rağmen, glazeli yüzeylere tutunmuştur. Biyolojik açıdan bakıldığında, glazelenmiş yüzeylerin klinik olarak kabul edilebilir olmadığı; glazelemenin, bakteri ve diğer maddelerin tutunmasını kolaylaştıran, düzensizliklere sahip, dalgalı ve pürüzlü bir yüzey oluşturduğu bildirilmiştir. Polisajlanmış porselen yüzeylerinin altında boşluklar ve mikroçatlaklar olduğu bildirilmesine rağmen, bu yüzeysel defektler yüzey pürüzlülüğüne veya plak adezyon miktarına katkıda bulunmadığı belirtilmiştir. Önceki çalışmaların aksine, plak birikimini önleyecek daha düzgün bir yüzey elde edilmesinde, elmas pat ile polisaj yapılmasının yararlı olacağını belirtmişlerdir.

Polisajlanmış ve glazelenmiş seramik yüzeylerinde streptokokal adezyonun incelendiği in vitro bir çalışmada, porselen örnekler 3 gruba ayrılmıştır. İlk grup elmas patla polisajlanmış, ikinci grup glazelenmiş, diğer grup ise $\mathrm{Al}_{2} \mathrm{O}_{3}$ frez ile polisajlanmıştır. Yüzey pürüzlülüğünde ilk iki grup arasında anlamlı fark yokken, üçüncü grup en pürüzlü yüzey özelliği göstermiştir. Bakteri adezyonunda ilk iki grup arasında yine anlamlı fark bulunmazken, en çok bakteri 
adezyonunun üçüncü grupta oluştuğu bildirilmiştir. Glazeleme ile karşılaştırıldığında seramik yüzeylerinin polisajlanmasının biyoadezyon açısından klinik olarak kabul edilebilir olduğu belirtilmiştir. ${ }^{37}$

Polisajlanmış ve glazelenmiş zirkonya seramikler de erken biyofilm oluşumunun incelendiği bir çalışmada, posterior bölgeye yerleştirilen örnekler 20 dakika veya 1 saat sonra ağızdan çıkarılarak SEM'de incelenmiştir. Glazelenmiş örneklerin polisajlanmış örneklere göre daha fazla yüzey pürüzlülüğü gösterdiği ve dental biyofilm oluşumuna daha yatkın olduğu bildirilmiştir. $^{38}$

Rosentritt ve arkadaşlarının ${ }^{39}$, zirkonya kor ve veneer cam seramiklere oral streptokok tutunmasını araştırdıkları in vitro çalışmalarında, üç veneer cam seramik ve üç zirkonya seramik materyali incelenmiştir. Farklı seramik materyallerinde yüzey pürüzlülüğü ve yüzey hidrofobisitesi değişiklik göstermiştir. Protein kaplanması, yüzeyleri hidrofilize etmiş ve farklı seramiklerin yüzey hidrofobisitesinin homojenizasyonuna yol açmaktadır. Protein kaplamasından önce, farklı seramiklerdeki streptokok adezyonunun benzer olduğu bulunurken, protein kaplamasından sonra daha belirgin farklar gözlenmiştir. Yüzey parametreleri ve streptokokal adezyon arasında zayıf korelasyon bildirilmiştir. Çalışmanın sınırlamaları ile birlikte, bu in vitro çalışmada, zirkonya ve cam seramikler arasında streptokokal adezyon açısından yalnızca küçük farklılıklar bulunmuştur. Bu sonuçların ışığında, in vivo olarak açığa çıkan zirkonya yüzeylerinde, cam seramik yüzeylerinden daha fazla plak birikmesinin mümkün olmadığı belirtilmiştir.

\section{Metal Alassumlarında Biyofilm}

Yalıtkan polimer yüzeylerle karşılaştırıldığında, metal yüzeylere bakteri adezyonunun mekanizmasındaki olası farklılıklar hakkında sınırlı bilgi mevcuttur. Ancak, altın ve amalgam gibi iletken materyallere bakteri adezyonunda elektron transferinin önemli rol oynadığı öne sürülmektedir. ${ }^{40}$ Ek olarak, negatif yüklü bir bakterinin iletken metale yaklaşması sonucu, iletken materyalde güçlü bir elektrostatik çekim kuvveti yaratan zıt yüklenmiş gibi bir durum oluşabilir. 2,41

Geçmişe bakıldığında, metal alaşımlarında mikroorganizma tutunumu ile ilgili nadir çalışmalara rastlanmaktadır. Metal alaşımlar üzerine yürütülen çalışmalar daha çok alaşımların dokulara biyouyumluluğu ve korozyonları üzerine odaklanmaktadır. Güncel çalışmalarda ise, dental döküm alaşımları bir kenara bırakılmış; implantoloji ile birlikte diş hekimliğinde kullanımı hızla yaygınlaşan titanyum ve alaşımlarına önem verilmiştir.

Dental döküm alaşımlarında bakteri tutunumu, birikimi ve plak oluşumu birçok faktör tarafından etkilenmektedir. Bakır ve gümüş içeren ve ortama salan alaşımların, belli temel metal alaşımlara göre antimikrobiyal olarak daha aktif olduğu in vitro çalışmalarla kanıtlanmıştır. ${ }^{42}$

Akça ve arkadaşlarının ${ }^{43}$ farklı sabit protetik restorasyon materyallerinde bakteri tutunmasını inceledikleri çalışmalarında, yüzey porselenleri altında kullanılan materyaller ( $\mathrm{Cr}-\mathrm{Ni}$, Empress 2 ingot ve InCeram) arasında $\mathrm{Cr}-\mathrm{Ni}$ alaşımının en az bakteriyel tutunmaya olanak sağladığı bildirilmiştir.

Grivet ve arkadaşlarının ${ }^{44}$, dental alaşımlara in vitro streptokokal adezyon üzerinde hidrofobisitenin etkisini araştırdıkları çalışmalarında, test edilen alaşımların hidrofobik, $S$. sanguinis, $S$. mutans ve $S$. oralis'in hidrofobik, $S$. mitis'in hidrofilik olduğu gösterilmiştir. Diğerlerine göre daha hidrofobik olan $S$. oralis, test edilen materyallere en yüksek adezyonu gösterirken; $S$. mitis hidrofobik yüzeylere en az adezyonu göstermiştir. Test edilen alaşımlar içerisinde, yüksek altın içeren alaşıma bakteri adezyonunun en yüksek, değersiz alaşımda en düşük olduğu tespit edilmiştir.

Çölgeçen ve arkadaşlarının ${ }^{45}$ yaptıkları in vitro çalışmada, dental nikel krom alaşımından hazırlanan örnekler elektrolitik yolla altın kaplanarak, yüzey pürüzlülüğü ve bakteri adezyonu üzerindeki etkileri incelenmiştir. Çalışmanın sonucunda, altın kaplama uygulanan grupta hem yüzey pürüzlülüğü hem de bakteriyel adezyon miktarının belirgin bir şekilde azaldığı tespit edilmiştir.

Özetle literatürde, bir veya bir grup alaşımın, iyi bir oral hijyen ile başa çıkılamayacak, plak birikimini arttırıcı özellik gösterdiklerine dair net bir bulgu yoktur. Ağırlıklı olarak in vitro ölçülen, belli alaşımların plak azaltıcı özelliklerinin klinik uygunluğu henüz gösterilememiştir. $\mathrm{Bu}$ nedenle, metal restorasyonlar söz konusu olduğunda, enflamasyon nedeni olan plağın kontrolü klinisyen ve hastanın sorumluluğundadır. ${ }^{42}$

\section{Yapısstırıcı Simanda Biyofilm}

Metal ve seramik restorasyonlarda yapıştırıcı sistemlerin uzun dönemde başarı oranları yüksektir. Yapılan klinik çalışmalarda, başarısızlığın temel nedeni olarak sekonder çürük gösterilmiştir. Karyopatojenik

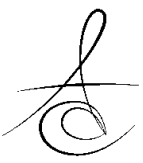


bakterilerin dişlere, restorasyonlara ve açıkta kalan siman yüzeylerine tutunması sonucu oluşan çürüğün başlangıcı için dental restorasyon kenarları oldukça duyarlıdır. ${ }^{46}$

Restorasyon ve diş arasındaki boşluk, yapıştırıcı siman ile dolmaktadır. Açıkta kalan siman miktarı birkaç $\mathrm{mm}^{2}$ olabilmektedir; bu nedenle siman, bakteriyel tutunum ve kolonizasyon için yüzey oluşturduğundan önem teşkil eder. ${ }^{47}$

Orstavik ve Orstavik ${ }^{47}$ bir çalışmalarında, 2 saat boyunca ağız içinde bekletilen çinko fosfat, polikarboksilat, çinko oksit-EBA, siliko-fosfat ve rezin siman örneklerinde bakteriyel kolonizasyonu incelemişlerdir. En az bakteri tutunumunun EBA simanda gözlemlendiği; diğer siman tipleri arasında anlamlı bir fark bulunmadığı bildirilmiştir.

Buergers ve arkadaşları ${ }^{46}$, Streptococcus mutans tutunumuna duyarlılığına göre çeşitli yapıştırıcı siman sistemlerini ve hatalı karışım oranlarının adezyon miktarına etkisini incelemişlerdir. Test edilen yapıştırma sistemleri arasında $S$. mutans'ın bağlanma potansiyeli açısından anlamlı fark bulunmuştur. Sıvı/toz ya da baz/katalizör oranlarındaki değişimler, adezyon miktarında önemli değişikliklerle sonuçlandığı; sıvı veya katalizör oranındaki artışın şiddetli $S$. mutans adezyonuna yol açtığı bildirilmiştir.

\section{Titanyum ve Zirkonyada Biyofilm}

Diğer protetik materyallere göre üstün biyolojik özelliklere sahip olan titanyum, endoosseöz implantlarda en çok kullanılan biyometal olmasının yanı sıra, protetik restorasyonlardaki kullanımı da gün geçtikçe artmaktadır. Titanyum yüzeylerinin fiziksel ve kimyasal çeşitli yüzey özellikleri, bu yüzeylere insan hücreleri ve bakterilerin tutunmasında etkili olmaktadır. Yüksek yüzey serbest enerjisine ek olarak pürüzlü titanyum abutment yüzeylerinde hızla bakteri plağı biriktiği bildirilmiştir. ${ }^{48}$

Bakteri tutunumu ile ilgili yapılan çeşitli in vitro çalışmalarda, yüksek seviyedeki yüzey serbest enerjisi ve pürüzlü yüzeylerin bakteriyel adezyonu arttırdığı gösterilmiştir. Bu durumda, yüksek yüzey serbest enerjisine sahip oldukları için titanyum abutmentlarda dişlerden daha fazla plak oluştuğu kabul edilebilir. Ancak bu durum uygun oral hijyenin sağlanmasıyla etkisiz hale getirilebilir. ${ }^{42}$

Titanyuma alternatif olarak zirkonya implant ve abutmentlar önerilmiştir. Son yıllarda implant materyallerinde biyoadezyonun değerlendirildiği çalışmalarda genellikle titanyum ve zirkonya karşılaştırılmıştır. ${ }^{49-52}$

Scarano ve arkadaşlarının ${ }^{49}$ yaptığı bir çalışmada, saf titanyum ve zirkonyum oksit disklerinde bakteri adezyonu in vivo olarak incelenmiştir. Premolar-molar bölgeye uygulanan hareketli akrilik apareyin bukkal yüzeyine yapıştırılmış, benzer yüzey pürüzlülüğüne sahip saf titanyum (kontrol) ve zirkonyum oksit (test) diskler 24 saat ağızda bekletilmiştir. Diskler çıkarıldıktan sonra bakteri ile kaplanan yüzey miktarı SEM ile değerlendirilmiştir. Zirkonyum oksit örneklerde bakteri ile kaplanan disk yüzeyi (\%12.1 \pm 1.96$)$, titanyum örneklerden (\%19.3 \pm 2.9$)$ anlamlı derecede daha düşük bulunmuştur.

Salihoğlu ve arkadaşlarının ${ }^{50}$ in vivo çalışmasında, zirkonyum oksit ve titanyum alaşımı abutmentlarda ve komşu dişetinde bakteri kolonizasyonu araştırılmıştır. Elde edilen bulgular ışığında, titanyum ve zirkonyum oksit yüzeylerin, periodontal patojenlerin sert ve yumuşak dokudaki adezyon ve kolonizasyonuna eğilim yönünden benzer özelliklere sahip olduğu bildirilmiştir.

Al-Radha ve arkadaşları ${ }^{52}$, titanyum ve zirkonya dental implant materyallerinin yüzey özelliklerini ve bu özelliklerin bakteri adezyonu üzerindeki etkisini inceledikleri çalışmalarında, polisajlanmış yarı stabilize zirkonya (PZ), zirkonya ile kumlanmış titanyum (TBZ), zirkonya ile kumlanmış ve asitle pürüzlendirilmiş titanyum (TBZA) ve kontrol grubu olarak da polisajlanmış titanyum (PT) karşılaştırılmıştır. PZ ve TBZ, PT'den daha düşük yüzey serbest enerjisi ve daha $a z$ yüzey ıslanabilirliği göstermiştir. $P Z$ ve TBZ yüzeyleri PT ile karşılaştırıldığında daha az oranda bakteri adezyonu göstermiştir. Zirkonya ve zirkonya ile kumlanmış titanyum yüzeylerinin titanyuma göre, özellikle tükürük ile kaplandıktan sonra bakteri adezyonunu azalttığı gösterilmiştir. Titanyumun zirkonya ile modifiye edilmesi sonucunda, bakteri adezyonunun azaltılmasında saf zirkonya materyali ile ayn yüzey özelliklerine sahip olacağı gösterilmiştir.

\section{SONUÇ}

Ağız içi sert ve yumuşak dokulara tutunan mikroorganizmaların giderilmesi, hem hastalar hem de hekimler için rutin bir mücadeledir. Protezlerde oluşan biyofilm konumu itibariyle zararsız gibi görünse de dental plakta olduğu gibi birçok probleme neden olabilmektedir. Bu nedenle, oral dokuların sağlığının 
sürdürülebilmesi için, protetik materyallerde biyofilm oluşma potansiyeli dikkate alınmalı, bakteriyel adezyonun en aza indirilmesi amacıyla protetik materyallere uygun ve gerekli yüzey bitirme işlemleri uygulanmalı ve protez plağı eliminasyonunun önemi hastalara hatırlatılmalıdır.

\section{KAYNAKLAR}

1. Subramani $K$, Jung RE, Molenberg A, Hammerle $\mathrm{CH}$. Biofilm on dental implants: a review of the literature. Int J Oral Maxillofac Implants. 2009;24:616-26.

2. Busscher HJ, Rinastiti M, Siswomihardjo W, van der Mei HC. Biofilm formation on dental restorative and implant materials. J Dent Res 2010;89:657-65.

3. Teughels W, Van Assche N, Sliepen I, Quirynen M. Effect of material characteristics and/or surface topography on biofilm development. Clin Oral Implants Res 2006;17:68-81.

4. Bremer F, Grade S, Kohorst P, Stiesch M. In vivo biofilm formation on different dental ceramics. Quintessence Int 2011;42:565-74.

5. Hannig C, Hannig M. The oral cavity--a key system to understand substratum-dependent bioadhesion on solid surfaces in man. Clin Oral Investig. 2009;13:123-39.

6. Kolenbrander PE, Ganeshkumar N, Cassels FJ, Hughes CV. Coaggregation: specific adherence among human oral plaque bacteria. FASEB J 1993;7:406-13.

7. Whittaker CJ, Klier CM, Kolenbrander PE. Mechanisms of adhesion by oral bacteria. Annu Rev MicroBiol 1996;50:513-52.

8. Radford DR, Challacombe SJ, Walter JD. Denture plaque and adherence of Candida albicans to denture-base materials in vivo and in vitro. Crit Rev Oral Biol Med 1999;10:99-116.

9. Nikawa $H$, Hamada $T$, Yamamoto $T$. Denture plaque--past and recent concerns. J Dent 1998;26:299-304.

10. Marsh PD. Dental plaque as a microbial biofilm. Caries Res 2004;38:204-11.

11. Coulthwaite L, Verran J Potential pathogenic aspects of denture plaque. $\mathrm{Br} \mathrm{J}$ Biomed Sci 2007;64:180-9.
12. Verran J Malodour in denture wearers: an illdefined problem. Oral Dis. 2005;11:24-8.

13. Nalbant $A D$, Kalkanci A, Filiz B, Kustimur $S$. Effectiveness of different cleaning agents against the colonization of Candida spp and the in vitro detection of the adherence of these yeast cells to denture acrylic surfaces. Yonsei Med J 2008;49:647-54.

14. Bal BT, Yavuzyilmaz $H$, Yücel M. A pilot study to evaluate the adhesion of oral microorganisms to temporary soft lining materials. J Oral Sci 2008;50:1-8.

15. Theilade E, Budtz-Jørgensen E, Theilade J Predominant cultivable microflora of plaque on removable dentures in patients with healthy oral mucosa. Arch Oral Biol 1983;28:675-80.

16. Theilade E, Budtz-Jørgensen E. Predominant cultivable microflora of plaque on removable dentures in patients with denture-induced stomatitis. Oral Microbiol Immunol 1988;3:8-13.

17. Lewis N, Ready D, Howlett J, Lee D, Cookson B, Wilson M. Culture-dependant detection of MRSA in angular cheilitis. J Dent Res 2006;85(Spec Issue C):Abstract 0401.

18. Teles FR, Teles RP, Sachdeo A, Uzel NG, Song XQ, Torresyap G, Singh M, Papas A, Haffajee AD, Socransky SS. Comparison of microbial changes in early redeveloping biofilms on natural teeth and dentuRes J Periodontol 2012;83:1139-48.

19. Ramage G, Tomsett K, Wickes BL, López-Ribot JL, Redding SW. Denture stomatitis: a role for Candida biofilms. Oral Surg Oral Med Oral Pathol Oral Radiol Endod 2004;98:53-9.

20. Atay A. Ağız dokularına Candida yapışması. Atatürk Üniv Diş Hek Fak. Derg 2007;17:46-50.

21. Babaç YG, Nalbant D. Oral kandidoz. TDB Dişhekimi Derg, 2006; Bilimsel ek, 17 TemmuzAğustos: 16-21.

22. Elguezabal N, Maza JL, Dorronsoro S, Pontón J Whole saliva has a dual role on the adherence of Candida albicans to poly(methylmetacrylate). Open Dent J 2008;2:1-4.

23. Bamford CV, d'Mello A, Nobbs AH, Dutton LC, Vickerman MM, Jenkinson HF. Streptococcus gordonii modulates Candida albicans biofilm formation through intergeneric communication. Infect Immun. 2009;77:3696-704. 
24. Avon SL, Goulet JP, Deslauriers N. Removable acrylic resin disk as a sampling system for the study of denture biofilms in vivo. J Prosthet Dent 2007;97:32-8.

25. Pereira T, Cury AA, Cenci MS, Rodrigues-Garcia RC. In vitro Candida colonization on acrylic resins and denture liners: influence of surface free energy, roughness, saliva, and adhering bacteria. Int J Prosthodont. 2007;20:308-10.

26. Radford DR, Sweet SP, Challacombe SJ, Walter JD. Adherence of Candida albicans to denture-base materials with different surface finishes. J Dent 1998;26:577-83.

27. Chandra J, Patel JD, Li J, Zhou G, Mukherjee PK, McCormick TS, Anderson JM, Ghannoum MA. Modification of surface properties of biomaterials influences the ability of Candida albicans to form biofilms. Appl Environ MicroBiol 2005;71:8795-801.

28. Tari BF, Nalbant D, Dogruman Al F, Kustimur S. Surface roughness and adherence of Candida albicans on soft lining materials as influenced by accelerated aging. J Contemp Dent Pract. 2007;8:18-25.

29. Wady AF, Machado AL, Zucolotto V, Zamperini CA, Berni E, Vergani CE. Evaluation of Candida albicans adhesion and biofilm formation on a denture base acrylic resin containing silver nanoparticles. J Appl MicroBiol 2012;112:1163-72.

30. Acosta-Torres LS, Mendieta I, Nuñez-Anita RE, Cajero-Juárez M, Castaño VM. Cytocompatible antifungal acrylic resin containing silver nanoparticles for dentuRes Int J Nanomedicine 2012;7:4777-86.

31. Morgan TD, Wilson $M$. Anti-adhesive and antibacterial properties of a proprietary denture cleanser. J Appl MicroBiol 2000;89:617-23.

32. Bal BT, Yavuzyılmaz H. Yumuşak astar maddeleri. Atatürk Üniv Diş Hek Fak. Derg 2006;16:53-60.

33. Boscato N, Radavelli A, Faccio D, Loguercio AD. Biofilm formation of Candida albicans on the surface of a soft denture-lining material. Gerodontology. 2009;26:210-3.

34. Hahnel S, Rosentritt M, Handel G, Bürgers R. Surface characterization of dental ceramics and initial streptococcal adhesion in vitro. Dent Mater 2009;25:969-75.
35. Aykent F, Yondem I, Ozyesil AG, Gunal SK, Avunduk MC, Ozkan S. Effect of different finishing techniques for restorative materials on surface roughness and bacterial adhesion. J Prosthet Dent 2010;103:221-7.

36. Kawai K, Urano M, Ebisu S. Effect of surface roughness of porcelain on adhesion of bacteria and their synthesizing glucans. J Prosthet Dent 2000;83:664-7.

37. Wang YN, Wen GJ, Shi B, Pan XH. Adhesion of oral microorganisms on dental porcelain polished and glazed. Zhonghua Kou Qiang Yi Xue Za Zhi. 2003;38:342-4.

38. Scotti R, Zanini Kantorski K, Scotti N, Monaco C, Valandro LF, Bottino MA. Early biofilm colonization on polished- and glazed-zirconium ceramic surface. Preliminary results. Minerva Stomatol. 2006;55:493-502.

39. Rosentritt M, Behr M, Bürgers R, Feilzer AJ, Hahnel S. In vitro adherence of oral streptococci to zirconia core and veneering glass-ceramics. J Biomed Mater Res B Appl BioMater 2009;91:25763.

40. Poortinga AT, Bos R, Busscher HJ Measurement of charge transfer during bacterial adhesion to an indium tin oxide surface in a parallel plate flow chamber. J Microbiol Methods. 1999;38:183-9.

41. Mei L, van der Mei HC, Ren Y, Norde W, Busscher $\mathrm{HJ}$ Poisson analysis of streptococcal bond strengthening on stainless steel with and without a salivary conditioning film. Langmuir 2009; 25: 6227-31.

42. Schmalz G, Garhammer P. Biological interactions of dental cast alloys with oral tissues. Dent Mater 2002;18:396-406.

43. Akca AE, Akca G, Gökce S, Sultan N, Özdemir A. Farklı sabit protetik restorasyon maddelerinde bakteri tutunmasının incelenmesi. Gülhane Tıp Dergisi 2005;47:251-5.

44. Grivet M, Morrier JJ, Benay G, Barsotti O. Effect of hydrophobicity on in vitro streptococcal adhesion to dental alloys. J Mater Sci Mater Med 2000;11:637-42.

45. Çölgeçen Ö, Kesim B, Abay S, Topal ES. Dental nikel krom alaşımına uygulanan altın kaplamanın yüzey pürüzlülüğü ve bakteri adezyonuna etkilerinin incelenmesi. Sağlık Bilimleri Dergisi 2011;20:217-26.

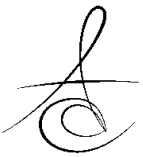


46. Buergers R, Hahnel S, Reischl U, Mueller R, Rosentritt M, Handel G, Behr M. Streptococcal adhesion to various luting systems and the role of mixing errors. Acta Odontol Scand 2009;67:13945.

47. Orstavik D, Orstavik J Two-hour bacterial colonization of dental luting cements in vivo. Acta Odontol Scand 1981;39:115-23.

48. Kuula H, Könönen $E$, Lounatmaa K, Konttinen YT, Könönen M. Attachment of oral gram-negative anaerobic rods to a smooth titanium surface: an electron microscopy study. Int J Oral Maxillofac Implants 2004;19:803-9.

49. Scarano A, Piattelli M, Caputi S, Favero GA, Piattelli A. Bacterial adhesion on commercially pure titanium and zirconium oxide disks: an in vivo human study. J Periodontol 2004;75:292-6.

50. Salihoglu U, Boynuegri D, Engin D, Duman AN, Gokalp P, Balos K. Bacterial adhesion and colonization differences between zirconium oxide and titanium alloys: an in vivo human study. Int J Oral Maxillofac Implants 2011;26:101-7.

51. Yılmaz HG, Yılmaz SK. Farklı abutment materyallerinin implant çevresi dokuların sağlığına etkileri. EÜ Dişhek Fak Derg 2011;32:69-75.

52. Al-Radha AS, Dymock D, Younes C, O'Sullivan D. Surface properties of titanium and zirconia dental implant materials and their effect on bacterial adhesion. J Dent 2012;40:146-53.

\section{Yazışma Adresi:}

Dt. İrem TÜRKCAN

Gazi Üniversitesi Diş Hekimliği Fakültesi

Protetik Diş Tedavisi Anabilim Dalı

Bişkek Caddesi, 1. Sokak No.4 Emek, Ankara, TÜRKİYE, 06510

Tel: 05368729596

Fax: 03122239226

E-mail: irem.turkcan@hotmail.com 